Group. One of the most intellectually exciting activities of its time, this group explored the transferability of administrative institutions from one nation and culture to another. Using the insights developed in his studies, Bill served as a chief participant in the Inter-University Research Program in Institution Building, involving scholars in a number of universities, and was active in the International Institute of Administrative Sciences, U.N. seminars on management, and the Eastern Regional (largely Asiatic) Organization for Public Administration.

He was never an ivory tower academic; he had more than an intellectual interest in public administration. During the 1950s he spent two years in Bangkok as one of the central participants in Indiana University's efforts to help the Thais deal with problems of public administration. In the sixties he lived in Honolulu for a year as a senior scholar at the EastWest Center. In the seventies, he was on leave from I.U. for two years to serve as director of the Office of Development Administration of the U.S. Agency for International Development, improving the quality of administration in many countries receiving - or hoping to receiveU.S. aid.

During the seventies and eighties, his work as director of Indiana University's International Development Institute and of the Program of Advanced Studies in Institutionbuilding and Technical Assistance Methodology placed him in the forefront of the continuing debate over issues of development administration and international technical assistance. He has been an advisor and consultant on management and administration for United Nations agencies, the Ford Foundation, the World Bank, and various individual foreign countries. In Thailand, where his close ties go back nearly forty years, he was awarded the rank of Commander in the Royal Order of the White Elephant by King Bhumipol.

In 1986, he received the first Fred Riggs Award from the Society of International Comparative Administration in honor of his contributions to the field, and a year later, won election to the National Academy of Public Administration. In
1991 he was the recipient of Indiana University's John W. Ryan Award for Distinguished Contribution to International Programs and Studies.

Throughout his career, Bill was an active and effective citizen of the academic communities of which he was a part. He was on the faculty of both the department of political science and the School of Public and Environmental Affairs; he was director of graduate studies for the department and a member of its executive committee, a member of the policy committee of the College of Arts and Sciences, and acting dean of international programs. For a number of years he represented Indiana University on the board of the Midwest Universities Consortium for International Activities. He was active in the American Society for Public Administration and the American Political Science Association-he was a member and chairman of the editorial board of PS.

For a dozen years before his death, Bill had health problems of increasing severity. He fully understood the seriousness of these problems, but would not admit or give in to them if he could avoid it, nor let them deter him from the things that he wanted to do. He continued to travel extensively, to consult, to write, to teach, with the same cheer and enthusiasm he had always had. It was completely characteristic of him that he was at his office, at his desk, doing some of the things that he wanted to do, on the last day of his life, in spite of his full acquaintance with his rapidly increasing physical frailty.

Eloquent, literate, amused, and brilliant, William J. Siffin brought energy, inspiration, charm, and perspective to a generation of colleagues, students, and friends. No one exposed to the Siffin wit and wisdom ever fully recovers, and each of us touched by his generous enthusiasm for knowledge and growth or zinged by his ferociously creative vocabulary cherishes the experience.

Byrum Carter

Alfred Diamant

York Willbern

Indiana University

\section{Aaron B. Wildavsky}

Aaron Wildavsky, age 63, died peacefully at his home in Oakland, California, of lung cancer on September 4,1993 . At the time of his death, he was Class of 1940 Professor of Political Science and Public Policy at the University of California at Berkeley, where he had taught since 1962. He was chairman of the political science department and founding dean of the Graduate School of Public Policy at Berkeley. From 1958-62 he taught at Oberlin College and he was briefly (in 1977) president of the Russell Sage Foundation. He held honorary degrees from Brooklyn College, his alma mater; Yale University, from which he had received his Ph.D.; and the University of Bologna, an honor conferred on the 900th anniversary of the university. He was president of the American Political Science Association in 1985-86, and was perhaps the most honored political scientist of his generation, at various times receiving prizes and awards named for Dwight Waldo, Charles E. Merriam, William Mosher, John Gaus, Harold Lasswell, Paul F. Lazarsfeld, and John Simon Guggenheim. His book, Politics of the Budgetary Process, was named by the American Society for Public Administration as the third most influential work in public administration in the last 50 years. He was a Fellow of the American Academy of Arts and Sciences, the National Academy of Public Administration, and the Center for Advanced Study in the Behavioral Sciences.

Wildavsky wielded an unusually prolific pen. He was author or coauthor of some 39 books (with more to come) and a great many articles and reviews, including important works on the budgetary process, policy analysis, political culture, foreign affairs, public administration, and comparative government. He wrote also on presidential elections and on the craft of political science. He taught assiduously and successfully, sending numerous Oberlin students on to graduate school, and sponsoring a large and devoted corps of Berkeley Ph.D.s.

The recitation of these accomplishments begins to suggest the pro- 
digious energy that Aaron Wildavsky brought to his vocation, but does not capture his unforgettable style, a mixture of Brooklynese breeziness and ferocious focus, a taste for paradoxical asides and a talent for penetrating insight. There is also his amazing breadth. An envious colleague once doubted that Wildavsky ever had a thought that went unrecorded. We will never know whether that is true; what we do know is that of those thoughts he did record, a very great many have formed the agenda for his fellow political scientists. The subfield of implementation, for example, got a powerful jump start from Wildavsky's book of that name with Jeffrey Pressman. Likewise the resuscitation of the study of public budgeting as a branch of the study of the politics of public organization dates from Wildavsky's Politics of the Budgetary Process. Wildavsky's studies of Moses and of Joseph opened the Bible as a political science text. His book with Hugh Heclo, The Private Government of Public Money, is by common opinion among the handful of great works on British public administration. At the time of his death, he was exploring the scientific claims of American environmentalists and the administrative styles of the middle third of the American presidents, among other projects.

Aaron Wildavsky was born May 31, 1930, in Brooklyn, New York, the son of Eva and Sender Wildavsky, who had emigrated to the United States from Poltava, in the Ukraine, some dozen years earlier. He grew up in the Brownsville section of Brooklyn, graduating from New York's PS 89, Erasmus Hall High School, and Brooklyn College. He served in the U.S. Army and in 1954-55 had a Fulbright Fellowship to the University of Sydney. In 1955 he embarked on graduate work at Yale and by 1958 completed his dissertation, Dixon Yates: $A$ Study in Power Politics, written under the supervision of Allan P. Sindler. There ensued as remarkably productive a career as the political science profession has ever seen.

Wildavsky is survived by his wife, Mary, four adult children by his previous marriage to the late Carol Shirk: Adam, Sara, Ben, and Dan, and by a granddaughter, Eva Miriam
Wildavsky, born September 5, 1993 to Ben and Rachel Wildavsky. He is survived also by legions of friends in America and abroad, by numerous students, collaborators and colleagues to whom he and his neverending stream of ideas were a constant stimulus and, in some cases, an inspiration.

Nelson W. Polsby

University of California at Berkeley

\section{Rudolf Wildenmann}

Rudolf Wildenmann, a leading figure in post-war German political science, passed away on July 14 in his 72nd year. Professor Wildenmann was well-known and admired by his American colleagues for his frequent participation in our professional meetings and for his guest lectureships at several American universities. What is perhaps less well known here is just what an important role he had played in rebuilding and reshaping modern German political science. It is no exaggeration to say that during the post-war period he helped create and nurture the development of empirical political science, with special emphasis on political behavior; thereby giving the field a new direction.

To Americans he is perhaps best known for pioneering the systematic study of voting behavior, utilizing modern empirical methodology. His study of the 1961 German general election was an early landmark in that field. It is through his efforts that German television (Channel 2) instituted regular, systematic analyses of electoral behaviors as well as monthly observations of the public's civic attitudes. Rudolf Wildenmann also has to be credited with the founding of ZUMA, a unique academic research institute located in Mannheim which focuses on basic social science research and innovative social science methodology.

In addition Wildenmann worked widely on the conduct and role of political parties in various regimes. He wrote numerous articles and monographs on the subject and was the main editor of a series on the future of party government. Another interest of his was the study of political elites and the consequence of various elite strategies for the wellbeing of the polis. That important work, begun in 1968, was conceived and executed as a longitudinal enterprise with subsequent studies in 1974 and 1981. Just prior to his death he was making preparations for a follow-up study on East-West German elites after unification.

Rudolf Wildenmann received his Ph.D. in 1952 from the University of Heidelberg. After a career as journalist and public servant, he obtained his habilitation in 1959 at the University of Cologne. In 1964 he assumed a professorship in political science at the University of Mannheim, three times becoming its rector (1967, 1969, and 1976). Upon his retirement he founded the Research Unit for Societal Development to which he invited scholars from different countries and disciplines whom he encouraged to collaborate in research on crucial problems evident in modern industrial nations. These efforts, under his guidance and frequent editorship, resulted in the publication of sixteen volumes covering a great variety of topics, from ecology to economics to party governance, and many more. This ability to attract and encourage the collaboration of scholars from many places and different disciplines and to draw in younger colleagues was perhaps his greatest forte. It is to this skill and his tireless efforts (together with those of Stein Rokkan and Jean Blondel) that we owe the European Consortium for Political Research where every year young political scientists come together at varying European universities to work on a joint project.

To a large extent all his efforts were animated by his deep concern for the development and nurture of democracy in the post-war German republic-a concern reflected already in his habilitation publication Macht und Konsensus als Problem der Innen- und Aussenpolitik. He never lost sight of that concern. This September he was to participate on an APSA panel on the topic. We shall miss him.

Roberta S. Sigel Rutgers University 